\title{
Butanol extract of Manihot esculenta leaf modulated cigarette butt leachate-mediated liver mitochondrial membrane permeabilization and its functional capacity
}

\author{
*Ajayi E.I.O., Iyoha A.E., Abdulazeez F.O.
}

\begin{abstract}
Objective: The experiment was designed to investigate the modulatory effects of the butanol extract of Manihot esculenta leaf, in vivo, and against the effects of cigarette butt leachate, in vitro on liver mitochondrial membrane permeability transition (MMPT), and its possible hepatoprotection in female Wistar rats.
\end{abstract}

Methods: The powdery form of fresh, air-dried and pulverized M. esculenta leaves were extracted in $95 \%$ butanol using Soxhlet apparatus and concentrated to a sticky mass using rotary evaporator. Ethical approval for animal use was obtained from Ladoke Akintola University of Technology, Osogbo, Nigeria (LTH/EC/2014/10/237). Twelve Wistar rats were randomly assigned into 2 groups of 6 rats each, and a separate group of 4 rats were used for the in vitro study. The first set of rats was orally treated daily with the extract for 21 days. Following an overnight fast, the rats were sacrificed by cervical dislocation and the liver mitochondria isolated by standard methods. Mitochondrial swelling and liver function assays were done spectrophotometrically.

Results: In vivo, the extract significantly induced low amplitude pore opening in the absence of exogenous $\mathrm{Ca}^{2+}$; whereas when it was present, the extract slightly inhibited same. Two concentrations of cigarette butt leachate caused appreciable low amplitude swelling in control and treated animals in the presence of $\mathrm{Ca}^{2+}$; in the absence of which highly significant inhibitory effects were observed at the same concentrations, in vitro. Significant increases were also recorded for AST, ALT, bilirubin, total protein and ALP, in vivo.

Conclusion: The extract showed promise for hepato-protection against cigarette butt leachate toxicity in the liver of normal rats in the presence of exogenous $\mathrm{Ca}^{2+}$, in vitro.

Keywords: Manihot esculenta leaf extract, cigarette butt leachate, mitochondrial membrane permeability transition pore, liver function

*Correspondence author

Ajayi E.I.O.(Ph.D)

http://orcid.org/0000-0001-6348-5840

Email: ebenezer.ajayi@uniosun.edu.ng

Diabetes and Other Infectious Diseases Group; Bioenergetics, Hormetics and Mitochondria Genetics Unit, Biochemistry Department, Faculty of Basic and Applied Sciences, College of Science, Engineering and Technology, Osun State University, Osogbo, Nigeria.

Research Journal of Health Sciences subscribed to terms and conditions of Open Access publication. Articles are distributed under the terms of Creative Commons Licence (CC BY-NC-ND 4.0). (http://creativecommons.org/licences/by-nc-nd/4.0)

http://dx.doi.org/10.4314/rejhs.v6i1.4 


\title{
Extrait de butanol de Manihot esculenta feuilleté de mégot de cigarette à médiation par lixiviat mitochondrial et sa capacité fonctionnelle
}

\author{
*Ajayi E.I.O., Iyoha A.E., Abdulazeez F.O.
}

\begin{abstract}
Resume
Objectif: L'expérience a été conçue pour étudier les effets modulatoires de l'extrait de butanol de Manihot esculenta in vivo et contre les effets du lixiviat des mégots de cigarettes in vitro sur la transition de la perméabilité membranaire mitochondriale du foie (MMPT) et son éventuelle hépatoprotection chez la femelle Rats Wistar.
\end{abstract}

Méthodes: La forme pulvérulente de feuilles de M. esculenta fraîches, séchées à l'air et pulvérisées a été extraite dans du butanol à $95 \%$ en utilisant un appareil Soxhlet et concentrée en une masse collante à l'aide d'un évaporateur rotatif. L'approbation éthique pour l'utilisation des animaux a été obtenue auprès de l'Université de Technologie Ladoke Akintola, Osogbo, Nigeria (LTH / EC / 2014/10/237). Douze rats Wistar ont été répartis au hasard en 2 groupes de 6 rats chacun, et un groupe séparé de 4 rats a été utilisé pour l'étude in vitro. Le premier groupe de rats a été traité par voie orale tous les jours avec l'extrait pendant 21 jours. Après un jeûne d'une nuit, les rats ont été sacrifiés par dislocation cervicale et les mitochondries du foie ont été isolées par des méthodes standard. Gonflement mitochondrial et les tests de la fonction hépatique ont été réalisés par spectrophotométrie.

Résultats: In vivo, l'extrait induit significativement une ouverture de pores de faible amplitude en l'absence de $\mathrm{Ca}^{2+}$ exogène; alors que lorsqu'il était présent, l'extrait inhibait légèrement le même. Deux concentrations de lixiviat de mégots de cigarettes ont provoqué un gonflement de faible amplitude appréciable chez les animaux témoins et traités en présence de $\mathrm{Ca}^{2+}$; en l'absence de quoi des effets inhibiteurs hautement significatifs ont été observés aux mêmes concentrations, in vitro. Des augmentations significatives ont également été enregistrées pour l'AST, l'ALT, la bilirubine, la protéine totale et l'ALP, in vivo.

Conclusion: L'extrait s'est avéré prometteur pour la protection hépatique contre la toxicité des lixiviats de mégots de cigarettes dans le foie de rats normaux en présence de $\mathrm{Ca}^{2+}$ exogène, in vitro.

Mots clés: Extrait de feuille de Manihot esculenta, lixiviat de mégots de cigarette, pore de transition de perméabilité membranaire mitochondriale, fonction hépatique

\footnotetext{
*Correspondance auteur

Ajayi E.I.O.(Ph.D)

http://orcid.org/0000-0001-6348-5840

Email: ebenezer.ajayi@uniosun.edu.ng
}

Diabetes and Other Infectious Diseases Group; Bioenergetics, Hormetics and Mitochondria Genetics Unit, Biochemistry Department, Faculty of Basic and Applied Sciences, College of Science, Engineering and Technology, Osun State University, Osogbo, Nigeria.

Research Journal of Health Sciences subscribed to terms and conditions of Open Access publication. Articles are distributed under the terms of Creative Commons Licence (CC BY-NC-ND 4.0). (http://creativecommons.org/licences/by-nc-nd/4.0)

http://dx.doi.org/10.4314/rejhs.v6i1.4 


\section{INTRODUCTION}

Cells under stress activate survival and death signaling pathways. Cell death signaling frequently converges on mitochondria, a process that is controlled by the activities of pro- and antiapoptotic BCL-2 proteins (1). Studies have shown that oxidative stress induces apoptosis $(2$, $3)$. Inhibition of the mitochondrial apoptosis pathway through pro-apoptotic BCL-2 proteins could prevent eventual release of cytochrome $\mathrm{c}$ from the mitochondrial intermembrane space to the cytosol (4). BCL-2, BCL-XL and MCL-1 modulation of $\mathrm{Ca}^{2+}$ signalling during oxidative stress may also play a vital role in nephroprotection. Hence manipulating the prosurvival BCL-2 family members may be beneficial in developing future therapies for neurodegenerative disorders (1). Calcium is a universal messenger regulating many physiological functions, including the ability of the cell to undergo apoptosis (5). In physiopathological conditions including diabetes, apoptotic processes become dysregulated, leading to tissue wastage due to excessive apoptosis. Compounds that inhibit pore opening, including lycopene, zeaxanthin, ginsenosides $\mathrm{Rg} 3$, ginkgolides $\mathrm{A}, \mathrm{B}$ and $\mathrm{C}$; withanolide, icarin, epimedoside and breviflavone could alter calcium levels (6).

The MMPT involves a sudden, and initially reversible increase in permeability of the inner mitochondrial membrane to solutes up to $1.5 \mathrm{kDa}$ due to the pore formed across the inner and outer membranes of mitochondria (7). The pore opening causes depolarization of the mitochondrial membrane potential, loss of the $\mathrm{H}^{+}$ gradient, uncoupling of oxidative phosphorylation, ATP depletion, and mitochondrial swelling $(8,9)$. It is commonly defined by its inhibition by potent inhibitors including spermine, cyclosporin $\mathrm{A}$ or their derivatives that bind to mitochondrial cyclophilin (peptidyl-prolyl-cis-trans-isomerase) such as Nmethyl-Val-4-cyclosporin A. Spermine- and cyclosporin A-mediated inhibition of the permeability transition is transient (lasting 60 min) (10). A diverse range of stimuli can control the MMPT in both isolated mitochondria and intact cells. Full-blown permeability transition causes uncoupling of the respiratory chain with collapse of the electrochemical proton gradient $\Delta \Psi \mathrm{m}$ and cessation of ATP synthesis, matrix $\mathrm{Ca}^{2+}$ outflow, depletion of reduced glutathione, depletion of NADPH, hypergeneration of superoxide anion, and mitochondrial release of intermembrane proteins (11). Several of the consequences of permeability transition themselves favour opening of the permeability transition pore, implying that permeability transition is a self-amplifying process (12). Periodic reversible opening of the permeability transition pore allows for the release of $\mathrm{Ca}^{2+}$ from the mitochondrial matrix, thereby participating in $\mathrm{Ca}^{2+}$ homeostasis and/or the generation of $\mathrm{Ca}^{2+}$ waves $\left(\mathrm{Ca}^{2+}\right.$-induced $\mathrm{Ca}^{2+}$-release) (13). The intrinsic (mitochondrial) pathway of apoptosis leads to the release of cytochrome $\mathrm{c}$ following two crucial events including massive colloidosmotic swelling of the mitochondrial matrix and rupture or bursting of the outer membrane. Indeed, this seemed to be the case in a number of experiments performed using isolated mitochondria in vitro $(14,15,16)$. The aim of this experiment therefore was to assess the effect of butanol extract of Manihot esculenta leaf on liver mitochondrial swelling in otherwise normal rats, in vivo; the modulatory effects of the extract pretreatment against cigarette butt leachate mutagenic perturbations of the mitochondrial membrane permeability transition pore opening, in vitro and the effects of oral administration of the extract on liver function.

Cassava leaves, particularly the first matured leaves and the tender petioles and stem are a major food in Africa (17). It has become a staple vegetable and forage in African countries such as Congo, Sierra Leone, Madagascar and Nigeria due to its richness in protein and betacarotenoids (18), the latter which are potent antioxidants (19).

Tobacco is the single greatest cause of preventable death in developed countries and an important cause of premature death worldwide. As many as half of people who use tobacco die from the results of this use. Each year, tobacco causes about 6 million deaths (about $10 \%$ of all deaths) with 0.6 million of these occurring in non-smokers due to second hand smoke (20). Environmental tobacco smoke or secondhand smoke has been shown to cause adverse health effects in people of all ages (21). The prevalence of cigarette smoking among youths and adults in Nigeria is high and alarming (22). In restaurants and bars, spent tobacco in the form of ashes and butts are handled and disposed indiscriminately leading to environmental pollution. Cigarette butts are the most usual form of litter in the world, as approximately 5.6 trillion cigarettes are smoked every year worldwide (23). Owing to the ubiquitous nature and magnitude of cigarette 
butts discharged into the environment; studies are needed to determine whether cigarette butt waste can exert 'mitotoxic' effects in the course of exposure to the leachate. A plethora of highly toxic chemicals are introduced to the environment via cigarette particulate matter (tar) and butt-ashes leachate. These may include carbon monoxide, hydrogen cyanide, nitrogen oxides, polycyclic aromatic hydrocarbons, ammonia, acetaldehyde, formaldehyde, benzene, phenol, argon, pyridines and acetone, over 50 of which are known to be carcinogenic to humans (24).

Smoked cigarette tobacco, (un)smoked cigarette filters litter waste bins, dumpsites and roadsides through which arsenic, nicotine, polycyclic aromatic hydrocarbons and heavy metals are released into the environment $(25,26$, 27). The risks of poisoning from these toxicants resulting from long-term exposure may manifest in many forms of cancer including kidney cancer (28), cancer of the larynx and head and neck (29, $30)$, bladder cancer (31), cancer of the esophagus (32), cancer of the pancreas (33) and stomach cancer(34).

\section{MATERIALS AND METHODS}

Plant and Cigarette Materials: Fresh $M$. esculenta leaves were collected from a farm in Osun State University, Osogbo. They were identified and authenticated (Voucher Number: UIH002/1094) by Mr. S. B. Adeyemi at the Plant Biology Department, University of Ilorin, Kwara State, and were deposited at the herbarium. The leaves were air-dried for three (3) weeks, and extracted in 95\% ethanol using Soxhlet apparatus. The extract was concentrated at a lower temperature under reduced pressure in a rotary evaporator (LIDA XMT-J7000/RE52-3 iDNA). The cigarette butt leachate was prepared by soaking $40 \mathrm{mg}$ cigarette ashes from the same cigarette brand in $2 \mathrm{ml}$ distilled water for 24 hours. This was spun in table centrifuge at $3000 \mathrm{X}$ $\mathrm{g}$ for 10 minutes and the supernatant was used for this study.

Animals and Treatment Regimen: Ethical approval for animal use was obtained from Ladoke Akintola University of Technology, Osogbo, Nigeria (LTH/EC/2014/10/237). The rats weighing about $80-120 \mathrm{~g}$ were kept in metabolic cages, acclimatized for 2 weeks, fed normal rat chow and allowed access to water, $a d$ libitum. After the acclimatization, the butanol extract was suspended in olive oil at $750 \mathrm{mg} / \mathrm{kg}$ and administered by oral gavage for 21 days. The separate group of 4 rats was used for the in vitro study over $200-1400 \mu \mathrm{g} / \mathrm{ml}$ extract concentration range.

\section{Liver Mitochondrial Membrane Permeability} Transition Pore Opening: At the end of the administration of butanol extract of $M$. esculenta leaf, liver mitochondria were prepared by the method of Sanz et al. (35) with slight modifications. Briefly, the rats were sacrificed by cervical dislocation and the livers dissected and trimmed to remove excess tissue, rinsed in Buffer $\mathrm{C}$, patted dry and weighed. The liver was then minced with a pair of scissors and poured into the homogenizing flask adding 10\% MSTHE buffer (210 mM mannitol, $70 \mathrm{mM}$ sucrose, 5mM TRIS and $5 \mathrm{mM}$ HEPES-KOH, pH 7.4 and $1 \mathrm{mM}$ EGTA) was added and then homogenized with Potter-Elvhenjam homogenizer. The whole process was carried out on ice to preserve the integrity of the mitochondria. The homogenized tissue was then implored into a high-speed cold centrifuge, where the nuclear fraction, unbroken cells and cell debris were sedimented by centrifugation at $2500 \times \mathrm{g}$ for 10 minutes. The supernatant was poured into a new centrifuge tube and the pellet was discarded. The supernatant was then centrifuging again at the speed of $9000 \times \mathrm{g}$ for 20 minutes to sediment the mitochondria pellets. The brown pellets were washed with MSTHE buffer containing 5\% BSA at $6000 \times \mathrm{g}$ for 10 minutes, after which the pellet was made homogenous following aspiration and suspension in MSTHE buffer lacking EDTA in aliquots kept on ice. The assessment of liver MMPT was done within 4 hours after mitochondria isolation following the protocol of Lapidus and Sokolove (7), which works on the principle that mitochondria that have accumulated calcium can be induced to undergo a permeability transition. The inner membrane becomes non-selectively permeable to small (1500 Daltons) solutes and show colloid-osmotic i.e. large amplitude swelling which results in a decreased photometric absorption at $540 \mathrm{~nm}$ as their refractive index changes so that less light is passed across the cuvette which results in a decrease in the light absorbance measured with a spectrophotometer. To avoid any complications that changes in the redox state of the respiratory chain components might cause, the wavelength of the incident light should be at the isobestic point from the cytochromes (520 nm or $540 \mathrm{~nm}$ ) as used in several studies on isolated 
mitochondria (7).

Thus, the rate of change in absorbance was monitored at $540 \mathrm{~nm}$ under energized and deenergized conditions using Camspec M106 spectrophotometer (Spectronic Camspec Ltd, UK), viz: liver mitochondria [(1.0 $\mathrm{mg} / \mathrm{ml}$ BSA equivalent, by protein determination following Lowry's method (36)] in MSTHE buffer were preincubated in the presence of $2 \mathrm{mM}$ rotenone, energized with $5 \mathrm{mM}$ sodium succinate to support swelling in the absence or presence of exogenous Calcium $\left(5.68 \mathrm{mM} \mathrm{CaCl}_{2}\right)$ and $1 \mathrm{mM}$ spermine as triggering and inhibiting agents, respectively. For the effects of the extract on the liver MMPT, in vitro, other additions were made to the reaction mixture in the cuvette $(200,600,1000$ and 14000 $\mu \mathrm{g} / \mathrm{ml}$ as $10,30,50$ and $70 \mu \mathrm{l}$, respectively). The incubation of the concentrations of cigarette butt leachate $(\mathrm{CBL})$ was done with mitochondria in the presence of $2 \mathrm{mM}$ rotenone at $30{ }^{\circ} \mathrm{C}$ for 3 minutes prior to the addition of $5.68 \mathrm{mM} \mathrm{CaCl}_{2}$, 30 seconds after which the assay was energised by $5 \mathrm{mM}$ sodium succinate.

Liver Function and Total Protein Quantification: Following sacrifice of the rats, sera were prepared from blood collected into plain tubes that were allowed to stand at room temperature for 5 minutes and spun in a table top centrifuge at $3000 \times \mathrm{g}$ for 20 minutes. Sera were stored at $-35^{\circ} \mathrm{C}$ till further use. Biochemical markers of liver function as well as total protein were determined thereafter. Aspartate aminotransferase (AST) and Alanine aminotransferase (ALT) activity and the bilirubin and total protein concentration were determined upon sacrifice after 5 days of treatment by standard methods using Randox ${ }^{\circledR}$ kits (England) following manufacturer's instructions. Absorbance for the respective parameter was read at the specified wavelengths $(\mathrm{nm})$ in CamSpec ${ }^{\circledR} 105$ UV-Vis spectrophotometer(UK).

Statistical Analyses: Data were analyzed with ANOVA (SPSS vs 20.0) and results were presented as Mean $\pm \mathrm{SD}(\mathrm{p}<0.05)$.

\section{RESULTS}

The results showed that the extract at 750 $\mathrm{mg} / \mathrm{kg}$ significantly $(\mathrm{p}<0.05)$ triggered low amplitude swelling $(-0.034 \pm 0.020,2$-fold $)$ compared to the control groups $(-0.017 \pm 0.006)$ in the absence of exogenous $\mathrm{Ca}^{2+}$; whereas in the presence of exogenous $\mathrm{Ca}^{2+}$, the extract slight inhibited spermine-sensitive liver MMPT pore opening compared to control $(-0.093 \pm 0.024$,
2.75 -fold; $-0.109 \pm 0.030,2.71$-fold, respectively). Concentrations of cigarette butt leachate $\left(200 \mu \mathrm{g} / \mathrm{ml}, \mathrm{CBL}_{10}\right.$ and $600 \mu \mathrm{g} / \mathrm{ml}$, $\mathrm{CBL}_{30}$ ) caused appreciable amplitude swelling of the pore in control $\left(-0.089 \pm 0.023, \mathrm{CBL}_{30}\right)$ and treated $\left(-0.063 \pm 0.019, \mathrm{CBL}_{10}\right)$ animals in the presence of $\mathrm{Ca}^{2+}$; while highly significant inhibitory effects were observed for the CBL in control and treated groups at $200 \mu \mathrm{g} / \mathrm{ml} \mathrm{(-}$ $\left.0.020 \pm 0.008, \mathrm{CBL}_{10}\right)$ and $600 \mu \mathrm{g} / \mathrm{ml}(-$ $0.024 \pm 0.020, \mathrm{CBL}_{30}$ ), respectively, in vitro. Significant increases were recorded for AST, ALT, bilirubin, total protein and ALP following oral administration of $750 \mathrm{mg} / \mathrm{kg} \mathrm{M}$. esculenta leaf compared to the control animals. There were significant increases $(p<0.05)$ in the concentrations of AST, ALT, total and direct bilirubin as well as total protein following oral administration of butane extract of $M$. esculenta leaf to otherwise normal rats: AST level was found to be significantly increased $(41.08 \pm 1.08$ $\mathrm{U} / \mathrm{L}$ vs $22.44 \pm 0.57 \mathrm{U} / \mathrm{L})$. ALT level also significantly in the treated animals compared to control group $(92.65 \pm 1.5 \mathrm{U} / \mathrm{L}$ vs $28.17 \pm 0.83$ $\mathrm{U} / \mathrm{L})$. Total bilirubin was less significantly increased following treatment compared to and direct bilirubin $(16.95 \pm 0.4 \mu \mathrm{mol} / \mathrm{L}, 81.83 \pm 0.2$ $\mu \mathrm{mol} / \mathrm{L} ; \quad 13.07 \pm 0.35 \mu \mathrm{mol} / \mathrm{L}, \quad 58.43 \pm 0.46$ $\mu \mathrm{mol} / \mathrm{L}$, respectively). Total protein level was also significantly increased by the extract treatment compared to the control group $(30.14 \pm 0.86 \mathrm{mg} / \mathrm{dL}$ vs $20.82 \pm 1.32 \mathrm{mg} / \mathrm{dL})$.

\section{DISCUSSION}

The extract had a significant induction effect of pore opening $(-0.034 \pm 0.02,2$ fold $)$ when compared to the status of the pore, ab initio in the absence of exogenous $\mathrm{Ca}^{2+}(-0.017 \pm 0.006)$. This may be a reflection of the ability of the extract to trigger cell death through the mitochondrial pathway. However, the apparently significant low amplitude swelling and induction effect of butanol extract of $M$. esculenta leaf on rat liver MMPT pore opening observed in the presence of $\mathrm{Ca}^{2+}$ (2.7 fold) significant mitoprotection in the control (2.71 fold). In the control group, in vitro perturbation of the liver MMPT pore opening by the concentrations of cigarette butt leachate $\left(\mathrm{CBL}_{10}\right.$ and $\left.\mathrm{CBL}_{30}\right)$ slightly induced (2.34 and 1.68 folds) compared to $\mathrm{Ca}^{2+}$ (2.71 fold); whereas following treatment, triggering of liver MMPT by $\mathrm{CBL}_{10}$ reduced to 1.60 -fold while that of $\mathrm{CBL}_{30}$ increased to 2.78 -fold. This may be a case of public health concern as accumulation of arsenic, nicotine, polycyclic aromatic hydrocarbons, heavy metals and a plethora of other toxicants 
from smoked cigarette tobacco, (un)smoked cigarette filters may overwhelm the liver. This concern is in consonance with the report of Moriwaki et al. (27) that smoked cigarette tobacco and (un)smoked cigarette filters litter waste bins, dumpsites and roadsides through which are released into the environment. Increased AST, ALT, bilirubin and total protein following administration of the extract suggest that though the extract improved protein synthesis by the liver, the rate of break-down of the proteins was also increased leading to elevated levels of bilirubin. The extract may also be toxic to the liver having caused cytolysis of plasma membrane of the hepatocytes as suggested by the increased AST and ALT levels (37).

\section{CONCLUSION}

The outcome of this research indicate that the butanol extract of $M$. esculenta possess certain hepatotoxic bioactive compounds that could induce liver MMPT pore opening in normal rats, in vivo. Oral administration of the same extract offered mitoprotection against cigarette butt leachate toxicity, in vitro in the liver of normal rats in the presence of exogenous $\mathrm{Ca}^{2+}$. Thus it can be concluded that the extract could be useful in the prevention of pore opening that could lead to the activation of the mitochondrial apoptotic pathway caused by exposure to cigarette waste.

Acknowledgements: The authors acknowledge the service of the technologists at the Biochemistry Department, Faculty of Basic and Applied Sciences, Osun State University, Osogbo, Nigeria.

Conflict of Interest: The authors declare that they do not have any conflict of interest or competing / financial interests.

\section{REFERENCES}

1. Ujval A. and Jochen H. M. P. Anti-apoptotic BCL2 family proteins in acute neural injury. Front Cell Neurosci. 2014, 8: 281.

2. Concannon C. G., Tuffy L. P., Weisova P., Bonner H. P., Davila D., Bonner C. et al. AMP kinasemediated activation of the $\mathrm{BH} 3$-only protein Bim couples energy depletion to stress-induced apoptosis. J. Cell Biol. 2010, 189, 83-94.

3. D'Orsi B., Bonner H., Tuffy L. P., Dussmann H., Woods I., Courtney M. J. et al. Calpains are downstream effectors of bax-dependent excitotoxic apoptosis. J. Neurosci. 2012, $32: 1847-1858$
4. Kilbride S. M. and Prehn J. H. Central roles of apoptotic proteins in mitochondrial function. Oncogene 2013, 32, 2703-2711 10.1038/onc.2012.348.

5. Dubois C., Fabien V. A., Natacha P. (2013). Targeting apoptosis by the remodelling of calcium-transporting proteins in cancerogenesis. FEBS Journal 280: 5500-5510.

6. Chucair A. J., Rotstein N. P., SanGiovanni J. P., During A., Chew E. Y., Politi L. E. Lutein a n d zeaxanthin protect photoreceptors from apoptosis induced by oxidative stress: relation with docosahexaenoic acid. Invest Ophthalmol Vis Sci. 2007, 48:5168-5177.

7. Lapidus R. G. and Sokolove P. M. Spermine inhibition of the permeability transition of isolated rat liver mitochondria: An investigation mechanism. Archives of Biochemistry and Biophysics 1993, 3061: 246-253.

8. Kroemer G. and Reed J. C. Mitochondrial control of cell death. Nat Med. 2000, 6:513-519.

9. Vieira H. L., Costantini P., Belzacq A. S., Larochette N., De Pablo M. A., Zamzami N. et al. Oxidation of a critical thiol residue of the adenine nucleotide translocator enforces Bcl-2independent permeability transition pore opening and apoptosis. Oncogene 2000, 19:307-314.

10. Zamzami N. and Kroemer G. The mitochondrion in apoptosis: how Pandora's box opens. Nat Rev Mol Cell Biol 2001, 2:67-71

11. Wei Y., Lin X. and Zhu C. Chiral separation of some $\beta$-blockers using electrophoresis with dual cyclodextrin systems. Canadian Journal of Analytical Sciences and Spectroscopy 2005, 50. 3: 135-140.

12. Crompton M. The mitochondrial permeability transition pore and its role in cell death. Biochem. J. 1999, 341: 233-249.

13. Woodfield K., Ruck, A., Brdiczka, D. and Halestrap, A. P. Direct demonstration of specific interactions between cyclophilin-D and the adenine nucleotide translocase confirm their role in the mitochondrial permeability transition. Biochemical Journal 1998, 336, 287-290.

14. Green D.R. and Kroemer G. The pathophysiology of mitochondrial cell death. Science 2004, 305: 626-629.

15. Anyasor G.N., Ajayi E.I.O., Saliu J.A., Ajagbonna O., Olorunsogo O. O. (2009). Artesunate opens mitochondrial membrane permeability transition pore. Ann Trop Med Public Health 2009, 2(2): 39-41.

16. Chipuk J., Moldoveanu T., Llambi F., Parsons M. and Green D. The BCL-2 family reunion. Mol Cell 2010, 37: 299-310.

17. Achidi A.U., Ajayi O.A , Bokanga M. and Maziya-Dixon B. The Use of Cassava Leaves as Food in Africa. Ecology of Food and Nutrition 2005, 44(6):423-435.

18. Parmar A., Sturm B. and Hensel O. Crops that feed the world: Production and improvement of cassava for food, feed, and industrial uses. Food 
Security 2017, 9(5):907-927

19. Fiedor J. and Burda K. Potential Role of Carotenoids as Antioxidants in Human Health and Disease. Nutrients 2014, 6(2):466-488.

20. World Health Organization WHO Report on the Global Tobacco Epidemic, 2008: The MPOWER Package. Geneva: World Health Organization 2008.

21. Vainio H. Is passive smoking increasing cancer risk? Scand. J Work Environ. Health 1987 13(3):193-196.

22. Ozoh O. B., Akanbi M. O., Amadi C. E., Vollmer $\mathrm{W}$. and Bruce N. The prevalence of and factors associated with tobacco smoking behavior among long-distance drivers in Lagos, Nigeria. Afr Health Sci. 2017, 17(3): 886-895.

23. Novotny T. E., Lum K. and Smith E. Cigarettes butts and the case for an environmental policy on hazardous cigarette waste. Int. J. Environ. Res. Public Health 2009, 6:1691-705.

24. Hoffmann D. and Hoffmann I. The changing cigarette, 1950-1995. J Toxicol Environ Health 1997, 50:307-64.

25. Warne MStJ, Patra R. W. and Cole B. Toxicity and a Hazard Assessment of Cigarette Butts t $\mathrm{t}$ Aquatic Organisms [abstract]. Interact 2002Programme and Abstract Book. Sydney: The Royal Australian Society Chemical Institute, the Australasian Society of Ecotoxicology and the International Chemometrics Society 2002, 192.

26. Micevska T., Warne MStJ and Pablo F. Variation in, and causes of, toxicity of cigarette butts to a cladoceran and microtox. Arch. Environ. Contam. Toxicol. 2006, 50: 205-12.

27. Moriwaki H., Kitajima S. and Katahira K. Waste on the roadside, 'poi-sute' waste: its distribution and elution potential of pollutants into environment. Waste Manag. 2009, 29:1192-1197.

28. Doll, R., Petro R. and Borelian J. Mortality in relation to smoking: 50 years' observations on male British doctors. BMJ 2004, 328(7455):1519.

29. Oreskes N. and Conway E. M. Merchants of Doubt: How a Handful of Scientists Obscured the
Truth on Issues from Tobacco Smoke to Global Warming. San Francisco, CA: Bloomsbury Press 2010. ISBN 1-59691-610-9.

30. Michaels D. Doubt is their product: how industry's assault on science threatens your health. Oxford [Oxfordshire]: Oxford University Press 2008, pp. 4-5. ISBN 0-19-530067-X.

31. Brandt A. M. The cigarette century: the rise, fall and deadly persistence of the product that defined America. New York: Basic Books, a member of the Perseus Books Group, 2007. IS B N 0-46507047-7.

32. Bjerregaard B. K., Raaschou-Nielsen O., Sørensen M., Frederiksen K., Tjønneland A., Rohrmann S. et al. The effect of occasional smoking on smoking-related cancers: in the European Prospective Investigation into Cancer and Nutrition (EPIC). Cancer Causes \& Control 2006, 17 (10): 1305-1309.

33. Pell J. P., Haw S., Cobbe S., Newby D. E., Pell A. C., Fischbacher C et al. Smoke-free legislation and hospitalizations for acute coronary syndrome. The New England Journal of Medicine 2008, 359 (5): 482-491.

34. Winickoff J. P., Friebely J. and Tanski S. E. Beliefs about the health effects of "thirdhand" smoke and home smoking bans. Pediatrics 2009, 123(1):e7479 .

35. Sanz A., Caro P. and Barja G. Protein restriction without strong caloric restriction decreases mitochondrial oxygen radical production and oxidative DNA damage in rat liver. J Bioenerg. Biomembr. 2004, 36:542-552.

36. Lowry O. H., Rosebrough N. J., Farr A. L. and Randall R. J. Protein measurement with the Folin phenol reagent. J Biol Chem 1951,193:265-75.

37. Shahjahan M., Sabitha K. E., Jainu M. and Shyamala-Devi C. S. Effect of Solanum trilobatum against carbon tetrachloride-induced hepatic damage in albino rats. Indian J. Med. Res. 2004, 120: $194-198$.

Table 1: Effects of butanol extract of Manihot esculenta leaf on some serum liver function parameters

\begin{tabular}{|c|c|c|c|c|c|}
\hline $\begin{array}{c}\text { Groups/ } \\
\text { Biomarkers }\end{array}$ & AST (U/L) & $\operatorname{ALT}(\mathbf{U} / \mathbf{L})$ & $\begin{array}{c}\text { T-BIL } \\
(\mu \mathrm{mol} / \mathrm{L})\end{array}$ & $\begin{array}{c}\text { D-BIL } \\
(\mu \mathrm{mol} / \mathrm{L})\end{array}$ & TP (mg/dl) \\
\hline Control & $22.44 \pm 0.57$ & $28.17 \pm 0.83$ & $13.07 \pm 0.35$ & $58.43 \pm 0.46$ & $20.82 \pm 1.32$ \\
\hline $\begin{array}{l}\text { Extract- } \\
\text { treated }\end{array}$ & $41.08 \pm 1.08^{*}$ & $92.65 \pm 1.50^{*}$ & $16.95 \pm 0.40^{*}$ & $81.83 \pm 0.20^{*}$ & $30.14 \pm 0.86^{*}$ \\
\hline
\end{tabular}




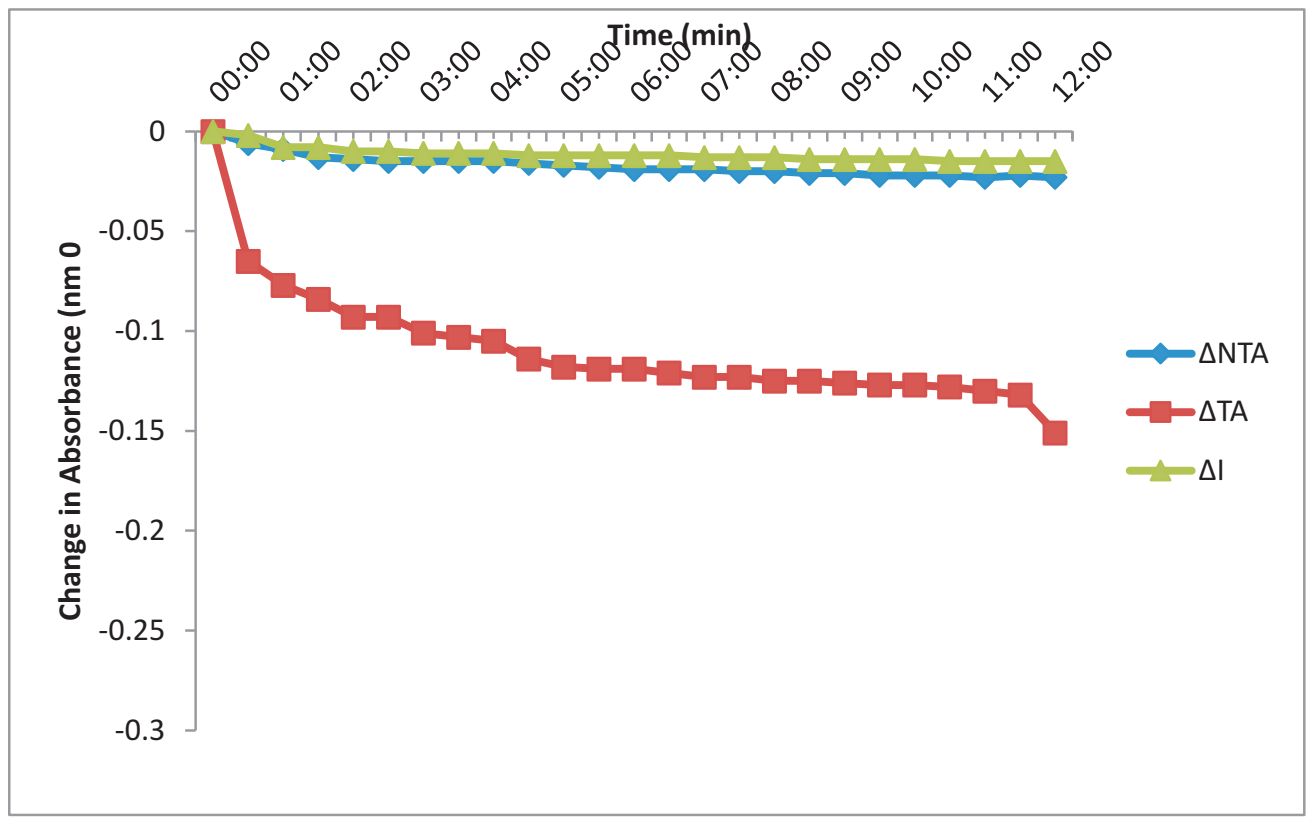

Figure 1: $\mathrm{Ca}^{2+}$-induced opening of liver mitochondrial membrane permeability transition (MMPT) pore and inhibition of the opening by Spermine in normal rats.

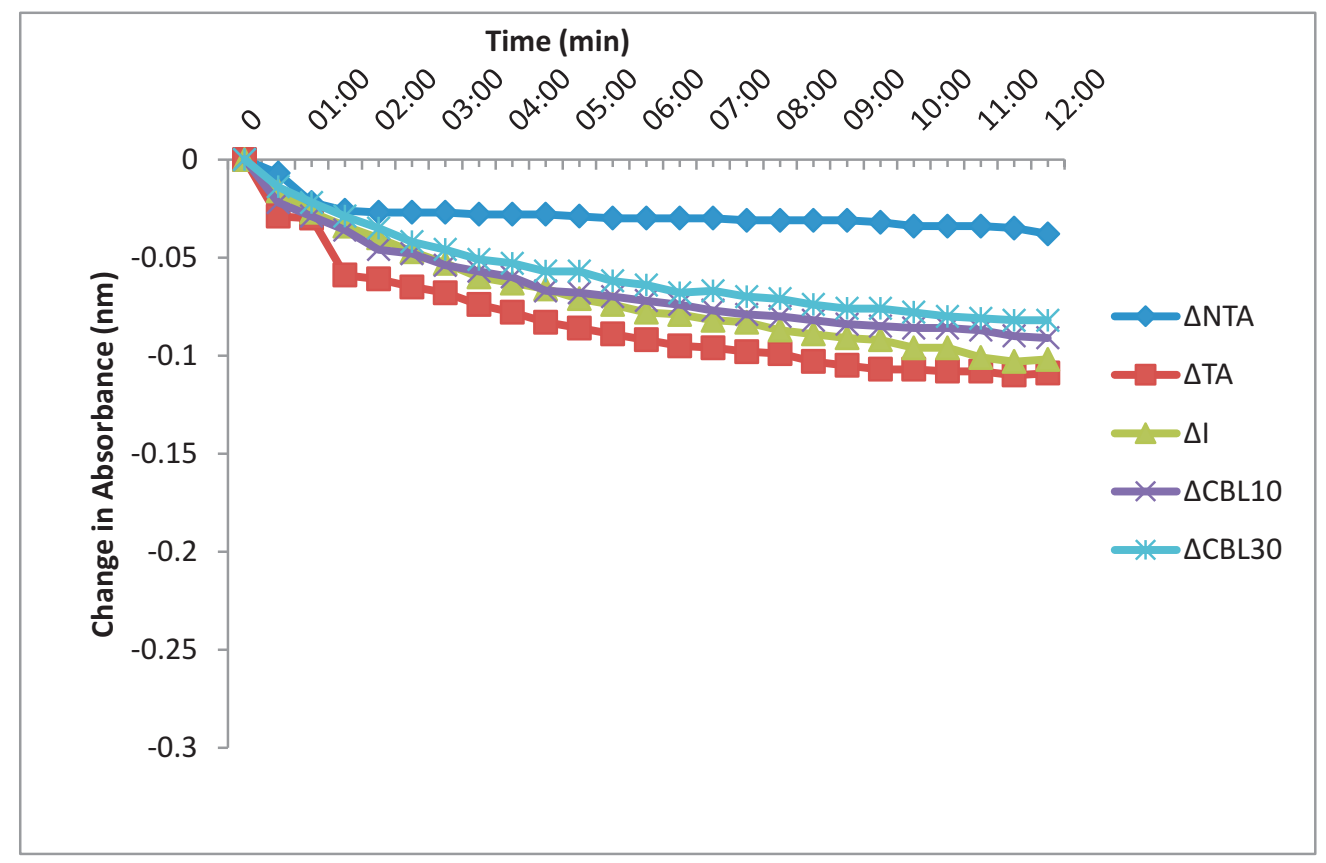

Figure 2 : The effect of varying concentrations of Cigarette Butt Leachate on liver MMPT Pore opening of Normal rat, in vitro. NTA: No Triggering Agent, TA: Triggering agent $\left(5.68 \mathrm{mM} \mathrm{CaCl}_{2}\right)$, I: Spermine inhibition, $\mathrm{CBL}_{10}: 200 \mu \mathrm{g} / \mathrm{ml}, \mathrm{CBL}_{30}: 600 \mu \mathrm{g} / \mathrm{ml}$. 


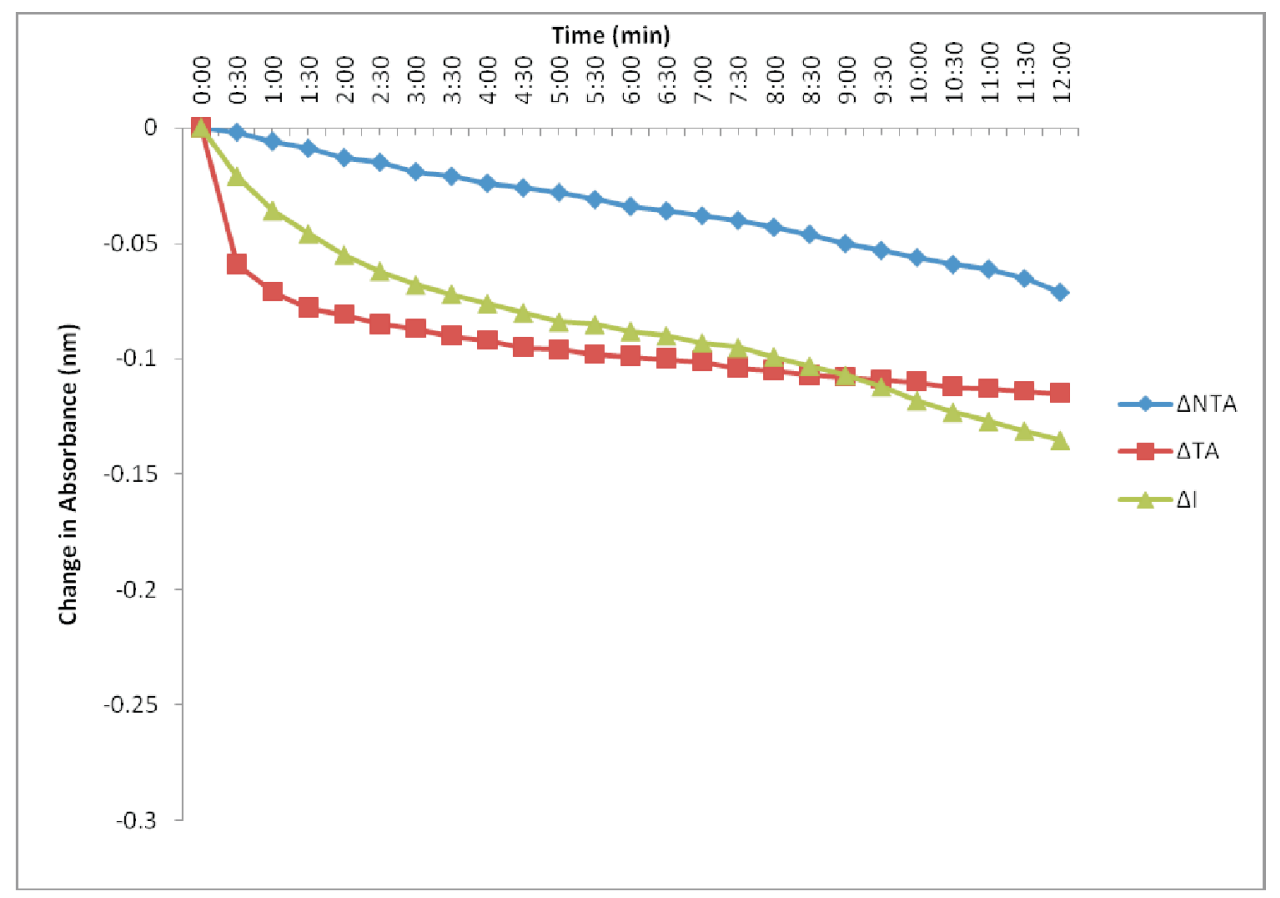

Figure 3: $\mathrm{Ca}^{2+}$-induced opening of liver mitochondrial membrane permeability transition (MMPT) pore in rat administered butanol extract of Manihot esculenta leaf.

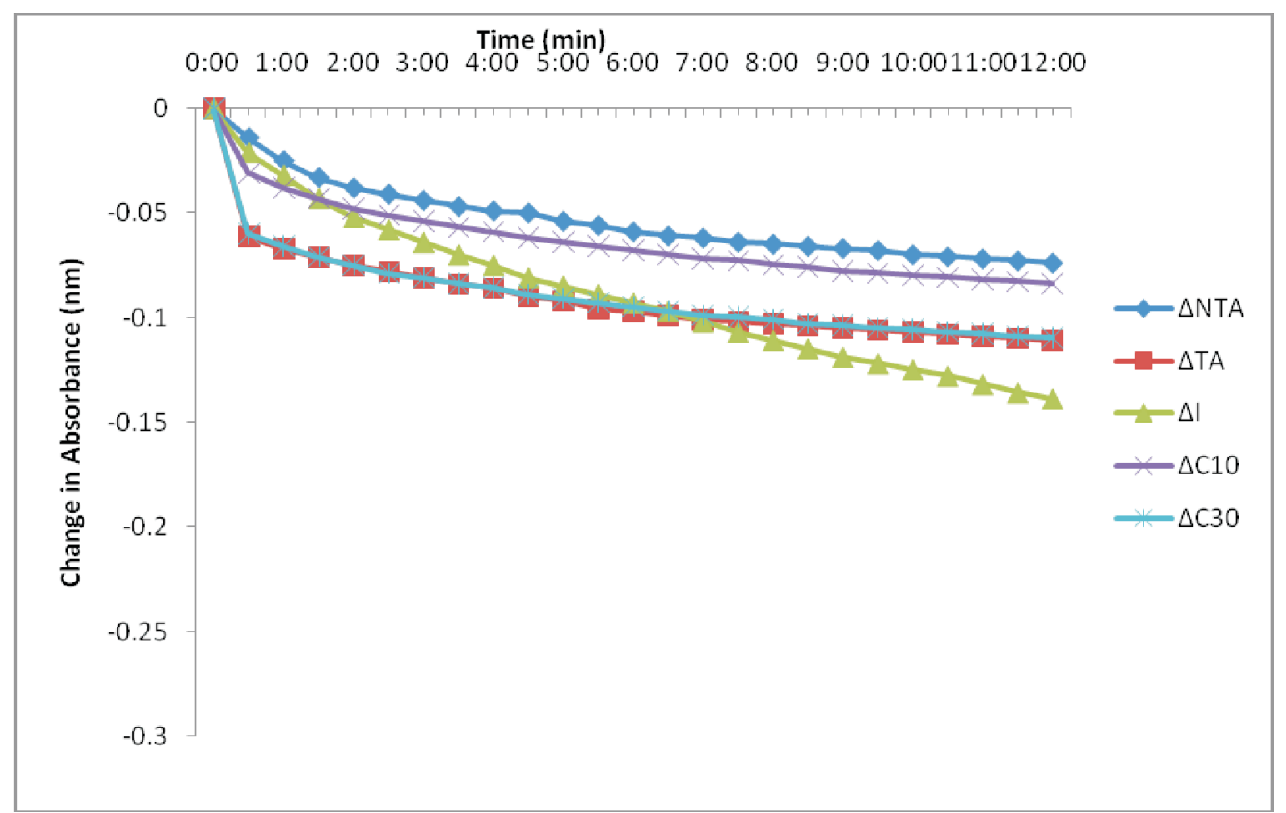

Figure 4 : Effect of M. esculenta on perturbation of rat liver MMPT pore opening by Cigarette Butt Leachate, in vitro. NTA: No Triggering Agent, TA: Triggering agent $(5.68 \mathrm{mM} \mathrm{CaCl} 2)$, I: Spermine inhibition, $\mathrm{CBL}_{10}$ : $200 \mu \mathrm{g} / \mathrm{ml}, \mathrm{CBL}_{30}: 600 \mu \mathrm{g} / \mathrm{ml}$. 